\title{
A serological study of cytomegalovirus infection in patients presenting with bad obstetric history attending Assam Medical College and Hospital
}

\author{
Liza Goswami, Kalpana Bezborah, Lahari Saikia \\ Correspondence: Dr. Liza Goswami, Department of Microbiology, Fakhruddin Ali Ahmed \\ Medical College, Barpeta, Assam; Email- drlizagoswami@gmail.com \\ Distributed under Creative Commons Attribution-Share Alike 4.0 International.
}

\begin{abstract}
Objective: To study the seroprevalence of Cytomegalovirus (CMV) infection in patients with bad obstetrics history (BOH). Methods: This study was carried out for a period of one year, from June 2012 to May 2013. A total of 80 cases were screened by Enzyme Linked Immunosorbent Assay for the presence of Cytomegalovirus specific IgG and IgM antibodies. The study population was divided into two groups - 40 randomly selected women with $\mathrm{BOH}$ and 40 normally pregnant women without any $\mathrm{BOH}$ attending Assam Medical College and Hospital. Results: CMV specific IgG antibodies were detected in $37(92.50 \%)$ of the patients with $\mathrm{BOH}$ and in $32(80 \%)$ of those without any $\mathrm{BOH}$. IgM antibodies were positive in $8(20 \%)$ of the patients with $\mathrm{BOH}$, while none of those without $\mathrm{BOH}$ were IgM seropositive. IgM seropositivity was found to be significantly associated with the patients with $\mathrm{BOH}(\mathrm{p}<0.05)$. Significantly higher prevalence rates of $\operatorname{IgG}$ were observed with increasing age $(\mathrm{p}$ value $<0.05)$ and declining socio-economic conditions. Conclusion: This study revealed high prevalence of seropositivity for CMV in women presenting with bad obstetric history. All these findings indicate that Cytomegalovirus infection is not uncommon in our local population and may play a vital role in determining the foetal outcome. Hence screening and prevention of CMV infection, especially in the pregnant women is very essential.
\end{abstract}

Keywords: Cytomegalovirus, bad obstetric history, screening.

Bad obstetric history $(\mathrm{BOH})$ implies previous unfavourable fetal outcome in terms of two or more consecutive spontaneous abortions, early neonatal deaths, stillbirths, intrauterine fetal deaths, intrauterine growth retardations and congenital anomalies. There might be different causes of $\mathrm{BOH}$ like genetic, hormonal, abnormal maternal immune response and maternal infection [1]. Cytomegalovirus (CMV), the largest member of the virus family Herpesviridae is a ubiquitous virus and one of the important causes of intrauterine infections [2]. Cytomegalovirus infections in pregnancy are major causes of maternal and foetal morbidity and mortality [3]. Maternal infections with Cytomegalovirus play a critical role in pregnancy with bad obstetric history and ultimately in the loss of foetus [4].

Received: $14^{\text {th }}$ June 2016. Accepted: $29^{\text {th }}$ July 2016.

Goswami L, Bezborah K, Saikia L. A serological study of cytomegalovirus infection in patients presenting with bad obstetric history attending Assam Medical College and Hospital. The New Indian Journal of OBGYN. 2017; 3(2): 86-9 
Serological surveys, in India have shown the prevalence of CMV antibodies in adult population to be about $80-90 \%[5,6]$. This study was undertaken to see the seroprevalence of Cytomegalovirus (CMV) infection in patients with bad obstetrics history.

\section{Materials and Methods}

This study was carried out for a period of one year, from June 2012 to May 2013 on patients presenting with or without bad obstetric history attending the Outpatient Department of Obstetrics \& Gynaecology as well as admitted in the Obstetrics \& Gynaecology ward of Assam Medical College \& Hospital. The ethical clearance was obtained from the Ethical Committee (Human) of Assam Medical College \& Hospital. Informed consent was obtained from all the women included in the study. A total of 80 cases were screened by Enzyme Linked Immunosorbent Assay (ELISA) for the presence of Cytomegalovirus specific IgG and IgM antibodies during the study period. The study population was divided into two groups as detailed below -

Group I (Study Group): This group comprised of 40 randomly selected women with bad obstetrics history (both past and present). This group of women presented with history of bleeding per vagina (included patients presenting with recurrent spontaneous abortion, threatened abortion, missed abortion), Intrauterine Growth Retardation (IUGR), Intrauterine Foetal Death (IUFD) and Preterm delivery.

Group II (Control Group): This group comprised of 40 randomly selected women attending Department of separated serum was then transferred to a sterile vial, labelled and stored at $-20^{\circ} \mathrm{C}$ till tested. The IgM capture ELISA and indirect IgG ELISA was done for all serum samples of the study using Platelia CMV IgM ELISA Kit and Platelia CMV IgG ELISA Kit from BIO-RAD, France for detection of serum IgM and IgG CMV antibodies following manufacturer's guidelines.

Data were analyzed, using Microsoft office 2010 and Graphpad Prism version 5.0. Statistical analysis was done with Chi-square test, Fischer's exact test with and without Yates correction wherever applicable.

\section{Results}

In our study, out of the 40 cases with bad obstetric history the maximum number of cases $(70 \%)$ belonged to the age group of $20-29$ years and $50 \%$ of the cases were from the lower socioeconomic class. The history of the $\mathrm{BOH}$ cases consisted of abortion in $14(35 \%)$, intrauterine death in $12(30 \%)$, intrauterine growth retardation in $11(27.50 \%)$, and premature delivery in 3 (7.50\%).

In this study, out of the 40 cases in the study group,

\begin{tabular}{|l|l|l|l|}
\hline \multicolumn{3}{|l|}{ Table 1: Serological profile of study and control group } \\
\hline Group & $\begin{array}{l}\text { Total } \\
\text { number of } \\
\text { sera tested }\end{array}$ & IgG Positive & $\begin{array}{l}\text { IgM } \\
\text { Positive }\end{array}$ \\
\cline { 2 - 4 } & 40 & $37(92.50 \%)$ & $8(20 \%)$ \\
\hline Study group & No (\%) & No (\%) \\
\hline Control group & 40 & $32(80.00 \%)$ & 0 \\
\hline
\end{tabular}

$20 \%$ were found to be positive for CMV IgM antibody and $92.50 \%$ were found to be positive for CMV IgG

\begin{tabular}{|c|c|c|c|c|c|c|c|}
\hline \multirow{2}{*}{$\begin{array}{l}\text { Obstetrics and } \\
\text { Gynaecology, }\end{array}$} & \multicolumn{7}{|c|}{ Table 2: Showing seropositive cases in the different age group } \\
\hline & \multirow{2}{*}{$\begin{array}{c}\text { Age } \\
\text { group } \\
\text { (in years) }\end{array}$} & \multicolumn{3}{|c|}{ Study group } & \multicolumn{3}{|c|}{ Control group } \\
\hline $\begin{array}{lr}\text { Assam } & \text { Medical } \\
\text { College } & \text { and }\end{array}$ & & $\begin{array}{l}\text { Serra tested } \\
\text { No }\end{array}$ & $\begin{array}{l}\text { IgG } \\
\text { No }(\%)\end{array}$ & $\begin{array}{l}\text { IgM } \\
\text { No (\%) }\end{array}$ & $\begin{array}{l}\text { Serra tested } \\
\text { No }\end{array}$ & $\begin{array}{l}\text { IgG } \\
\text { No (\%) }\end{array}$ & $\begin{array}{l}\text { IgM } \\
\text { No (\%) }\end{array}$ \\
\hline Hospital, & $<20$ & 7 & $4(66.66 \%)$ & $1(14.28 \%)$ & 9 & $5(55.55 \%)$ & 0 \\
\hline Dibrugarh. & $20-29$ & 28 & $28(100 \%)$ & $6(21.42 \%)$ & 23 & $19(82.60 \%)$ & 0 \\
\hline without any nast & $30-39$ & 5 & $5(100 \%)$ & $1(20.00 \%)$ & 8 & $8(100 \%)$ & 0 \\
\hline
\end{tabular}

or present bad obstetrics history.

Five $\mathrm{ml}$ of venous blood was collected aseptically in a sterile vial. The serum was separated by centrifuging the blood in a centrifuge machine at 1000 revolutions per minute for 5 minutes to avoid haemolysis. The antibody. In the control group, out of 40 cases $80 \%$ were positive for $\operatorname{IgG}$ antibody whereas none of the cases were found to be positive for CMV IgM antibody. IgM seropositivity was found to be 
significantly associated with the study group of patients

\begin{tabular}{|l|l|l|l|l|l|l|}
\hline \multicolumn{7}{|l|}{ Table 3: Seropositive cases in different socioeconomic groups } \\
\hline \multirow{3}{*}{$\begin{array}{l}\text { Socioeconomic } \\
\text { status }\end{array}$} & Study group & \multicolumn{2}{l|}{ Control group } \\
\cline { 2 - 7 } & $\begin{array}{l}\text { Serra } \\
\text { tested }\end{array}$ & $\begin{array}{l}\text { IgG } \\
\text { No (\%) }\end{array}$ & $\begin{array}{l}\text { IgM } \\
\text { No(\%) }\end{array}$ & $\begin{array}{l}\text { Serra } \\
\text { tested }\end{array}$ & $\begin{array}{l}\text { IgG } \\
\text { No(\%) }\end{array}$ & $\begin{array}{l}\text { IgM } \\
\text { No(\%) }\end{array}$ \\
\hline Lower & 2 & $2(100 \%)$ & $1(50 \%)$ & 2 & $2(100 \%)$ & 0 \\
\hline Upper lower & 20 & $20(100 \%)$ & $6(33.33 \%)$ & 25 & $20(80 \%)$ & 0 \\
\hline Lower middle & 14 & $13(92.80 \%)$ & $1(7.14 \%)$ & 11 & $9(81.80 \%)$ & 0 \\
\hline Upper middle & 4 & $2(50 \%)$ & 0 & 2 & $1(50 \%)$ & 0 \\
\hline Upper & 0 & 0 & 0 & 0 & 0 & 0 \\
\hline
\end{tabular}

countries whereas higher rates of HCMV-IgG antibody

prevalence $\quad(90-100 \%)$ have been reported in developing countries. These rates mostly depend on the variability of viral accessibility and its circulation rate in the community [9].

In the present study, with bad obstetric history $(\mathrm{p}<0.05)$ (table 1$)$.

In the study group, IgG seropositivity was found to be significantly associated with increasing age

\begin{tabular}{|l|l|l|l|}
\hline $\begin{array}{l}\text { Table 4: Seropositive cases according to different } \\
\text { presenting features }\end{array}$ \\
\hline Presenting features & $\begin{array}{l}\text { Serra } \\
\text { tested }\end{array}$ & $\begin{array}{l}\text { IgG } \\
\text { No(\%) }\end{array}$ & $\begin{array}{l}\text { IgM } \\
\text { No(\%) }\end{array}$ \\
\hline Bleeding per vagina & 14 & $14(100 \%)$ & $3(21.40 \%)$ \\
\hline Preterm delivery & 3 & $3(100 \%)$ & 0 \\
\hline IUFD & 12 & $11(91.6 \%)$ & $3(27.30 \%)$ \\
\hline IUGR & 11 & $9(81.8 \%)$ & $2(22.22 \%)$ \\
\hline
\end{tabular}

$(\mathrm{p}<0.05)$. A decline in seropositivity with rising socioeconomic status was observed and the difference between the upper and lower class was statistically significant $(\mathrm{p}<0.05) \quad$ (table 2, table 3). The seropositivity according to the presenting features among the cases with bad obstetric history for $\operatorname{IgG}$ and IgM antibodies is shown in table 4 .

\section{Discussion}

It is evident that maternal infections play a critical role in pregnancy wastage and their occurrence in patients with $\mathrm{BOH}$ is a significant factor [7]. Primary CMV infection during pregnancy carries a high risk of the intrauterine transmission which may result in severe fetal damage, including growth retardation, jaundice, hepatospleenomegaly and CNS abnormalities [8]. The prevalence of HCMV antibodies in women in childbearing age varies greatly in different population groups. Lower rates of HCMV-IgG antibody prevalence $(40-80 \%)$ have been reported in developed
37 cases $(92.50 \%)$ out of total 40 cases, in the study group were found to be positive for CMV IgG antibody indicating past infection. This finding is similar to Sadik MS [10]. The seropositivity of CMV IgM, in the present study was found in 8 out of 40 cases $(20 \%)$ indicating primary or recurrent infection. This finding was found to be similar with Hama SA [11]. Moreover, in the present study 8 patients in the study group who had positive serology for CMV IgM were also seropositive for CMV IgG. Thus the prevalence of IgM antibody to CMV in the study population is evidence of recurrent infection i.e reactivation of latent CMV infection or re-infection with a different strain of the virus.

Age is one of the risk factors that affect the seroprevalence of both CMV IgM and IgG antibodies [6]. In the present study, the highest seropositivity for CMV IgG (100\%) and CMV IgM (21.40\%) was found in the 20-29 years of age group. These findings are in accordance with other finding from India and abroad. In this study, statistically significant difference in CMV IgG seropositivity was found in the lower socioeconomic group including both lower and upper lower group and the lower middle and upper middle socioeconomic group. Similar observations have been reported from other studies [12]. Various factors associated with lower socioeconomic status such as crowding, low household income and poor hygiene were all associated with CMV seropositivity [13].

\section{Conclusion}

This study revealed high prevalence of seropositivity for CMV in women presenting with bad obstetric history as compared to women without any 
obstetric complications. All these findings indicate that cytomegalovirus infection is not uncommon in our local population. Nevertheless, it is well documented risk factor for $\mathrm{BOH}$ and may play a vital role in determining the foetal outcome. The screening of pregnant women for CMV infection by serological testing is currently not routinely recommended. But in areas like Assam where there is high prevalence of CMV infection screening can play an important role in alerting the physician/pediatrician regarding possible infection to the newborn.

\section{Conflict of interest: None. Disclaimer: Nil.}

\section{References}

1. Kumari N, Morris N, Dutta R. Is screening of TORCH worthwhile in women with bad obstetric history: an observation from eastern Nepal. J Health Popul Nutr. 2011; 29: 77-80.

2. Nelson CT, Demmler GJ. Cytomegalovirus infection in the pregnant mother, fetus, and newborn infant. Clin Perinatol. 1997; 24: 151-61.

3. Marino T. Viral Infections and Pregnancy. 2012. Available from: http://www. emedicine.medscape.com/article/235213-overview.

4. Mookerjee N, Gogate A, Shah PK. Microbiological evaluation of women with bad obstetric history. Ind J Med Res. 1995; 102: 103-7.

5. Mukundan P, Jadvan M, et al. Prevalence of Cytomegalovirus antibody in young children in Vellore. Ind J Med Res. 1977; 65: 589-92.

6. Mathur A, Jindal L, et al. A serological study of Cytomegalovirus infection at Lucknow. Ind J Med Res. 1981; 73: 678-81.
7. Surpam RB, Kamlakar UP, Khadse RK, et al. Serological study for TORCH infections in women with bad obstetric history. J Obstet Gynecol India. 2006; 56: 41-3.

8. Daiminger A, Bader U, Enders G. Pre- and periconceptional primary cytomegalovirus infection: risk of vertical transmission and congenital disease. Obstet Gynecol Surv. 2005; 60: 420-22.

9. Prince HE, Leber AL. IgM Levels validation of an inhouse assay for Cytomegalovirus immunoglobulin $\mathrm{G}$ (CMV IgG) avidity and relationship of avidity to CMV. Clini Diag Lab immiunol. 2002; 9: 824-27.

10. Sadik MS, Fatima H, Jamil K, Patil C. Study of TORCH profile in patients with bad obstetric history. Biology and Medicine. 2012; 4: 95-101.

11. Hama SA, Abdurahman KJ. Human Cytomegalovirus $\mathrm{IgG}$ and IgM seropositivity among pregnant women in Sulaimani City and their relations to the abortion rates. Current Research Journal of Biological Sciences. 2013; 5: 161-7.

12. Sheevani, Jindal N, Aggarwal A. A pilot seroepidemiological study of cytomegalovirus infection in women of child bearing age. Indian Journal of Medical Microbiology. 2005; 23: 34-6.

13. De Jong MD, Galasso GJ, Gazzad B, Griffith PD, Jabs DA, Kern ER, et al. Summary of the II international symposium on cytomegalovirus. Antiviral-Res. 1998; 39: 141-62.

\footnotetext{
Liza Goswami ${ }^{1}$, Kalpana Bezborah ${ }^{2}$, Lahari Saikia ${ }^{3}$

${ }^{1}$ Demonstrator, Department of Micobiology, Fakhruddin Ali Ahmed Medical College, Barpeta, Assam, India; ${ }^{2}$ Professor \& HOD, Department of Microbiology, Tezpur Medical College; ${ }^{3}$ Professor \& HOD, Department of Microbiology, Assam Medical College, Dibrugarh, Assam.
} 